\title{
Herpes Simplex Virus-Induced Destructive Corneal Disease
}

\author{
C. STEPHEN FOSTER
}

Boston

Recurrent herpes simplex keratitis (HSK) is a major contributor to the production of morbidity from corneal blindness around the world. That blindness results from loss of corneal clarity, secondary to the damage produced by the individual's immune/inflammatory responses to encounter with herpes simplex virus (HSV). Modification of the individual's inflammatory response to $\mathrm{HSV}$ in such a way that such corneal damage is minimised would, therefore, be a major advance in the global fight against blindness secondary to HSK. This is a complex challenge, since currently available strategies for modifying the host's immune response to HSV simultaneously impair the hosts' ability to control the replicating, productive HSV recurrent infection. An important goal, therefore, is to define, precisely, the cellular and molecular details of immunologic responses to HSV encounter in the cornea. Our research, in a defined murine model of necrotising HSK, shows that gene products from a highly restricted region on Chromosome 12, the Igh 1 region, profoundly influence the susceptibility to or resistance from destructive keratopathy after HSV corneal encounter. The Igh 1 locus encodes for synthesis of immunoglobulin heavy chain. The possible explanations why this gene or others closely linked to it might have such a profound influence on inflammatory responses to HSV encounter in the cornea, and therapeutic strategies designed to selectively modify these responses without impairing the host's ability to eliminate the virus are currently being studied.

This presentation is restricted to herpes simplex virus-induced destructive corneal disease. Given the fact that nearly a half million cases of herpes simplex keratitis (HSK) occur each year in the United States alone, the epidemiological importance of HSK as a leading cause of corneal blindness in developed countries has not been overemphasised. Incidence and prevalence data strongly suggest that in spite of the availability of newer, better, antiviral drugs, the ocular problems produced by herpes simplex virus are increasing at alarming rates. Herpes simplex epithelial keratitis is not a destructive disease. The impressive destruction and loss of function of the eye attendant to herpes simplex virus infections of the cornea results from recurrent infectious herpes simplex keratitis and its associated inflammatory and host immune responses which destroy the normal architecture and clarity of the corneal stroma. I will therefore limit my remarks to herpes simplex stromal keratitis.

Our current state of knowledge regarding the cellular and molecular details of the pathogenesis of stromal HSK are incomplete. Available data strongly suggest, however. that an extraordinarily delicate balance between protective responses and responses which produce sufficient corneal damage to result in loss of function exists at all times in an individual whose trigeminal ganglion has been colonised by herpes simplex virus. This dynamic balance

Correspondence to: Dr. C. Stephen Foster, Massachusetts Eye and Ear Infirmary, 243 Charles Street, Boston, MA 02114.

Presented in part at the One Hundred and Twenty-Third Annual Meeting of the American Ophthalmological Society, Carlsbad, California, 1987. 
may (indeed does) change longitudinally throughout the life of the individual.

Infectious-lytic viral replication with resultant cell rupture can, of course, participate in damage to host tissue. Viral factors undoubtedly influence not only the degree of host tissue damage produced through this mechanism but also the likelihood of subsequent violent postinfectious inflammatory responses to viral antigens and/or altered host tissue antigens. ${ }^{1}$ The available evidence, however, strongly suggests that massive stromal cell damage as a result of this mechanism of stromal cell (keratocyte) rupture is uncommon. ${ }^{2}$ Attempts to isolate infectious virions from individuals with fulminant necrotising stromal herpes keratitis and/or to identify, by electron microscopy, complete virions in corneal specimens from such individuals have produced variable results, and, on balance, have not supported the idea of an overwhelming lytic infection as an explanation for the stromal scarring or destruction.

The attendant host immune response, on the other hand, is a notable contributor to the corneal damage resulting from HSK. Histopathologic and immunopathologic analyses of corneal specimens from individuals with necrotising stromal HSK exhibit massive neutrophil and macrophage infiltration of the stroma. Liberation of the collagenolytic and proteolytic enzymes from these cells produces collagen and proteoglycan damage. Experimental animal studies of models of necrotising stromal HSK also show massive infiltration of the corneal stroma with these cell types, with associated destruction of the corneal stroma. ${ }^{3}$ Experiments designed to eliminate immunocompetent cells demonstrate that these cell types are critical for the recruitment of the inflammatory cells responsible for the production of the characteristic pathema of the cornea after HSV corneal inoculation. ${ }^{4}$

Both antibody-dependent and cell-dependent mechanisms are theoretically capable of producing host cell damage. Antibodyassisted host tissue damage may result from at least four mechanisms.

(1) Anti-herpes antibody, through opsonisation of the virus, enhances macrophage and neutrophil attraction and activity against the viral particles.
(2) Anti-herpes antibody binding to viral glycoproteinsexpressed on the cell surface of an infected corneal cell, followed by binding of the various components of complement can result in lysis of the infected cell.

(3) Binding of anti-herpes antibody (particularly $\mathrm{IgG}_{1}$ and $\mathrm{IgG}_{3}$ ) even in miniscule amounts, can stimulate an attack on the infected cell by cytotoxic cells called $\mathrm{K}$ cells, the effector cells responsible for the antibody dependent cellular cytotoxicity reaction or ADCC.

(4) Finally, antibody may participate in host pathology through the formation of herpes antigen-antiherpes antibodycomplement complexes which lodge at certain sites, including vessels, producing immune complex disease through the recruitment of neutrophils and macrophages to the area of immune complex deposition.

Acquired cellular immune mechanisms which may participate in host tissue damage during the immune response to HSK include antigen-specific (HSV) cytotoxic T-cell and delayed-type hypersensitivity (DTH) responses. In the former the cytotoxic T-cell may damage host cells expressing HSV glycoproteins on their surfaces by direct contact with the infected cells (with resultant cell lysis), by liberation of a lymphokine called lymphotoxin, which lyses the infected cell, or by recruitment of other cells, such as macrophages, through the release of chemoattractant lymphokines. DTH responses to HSV result in recruitment primarily of macrophages which produce the resultant clinically-evident tissue damage.

An example of destructive HSK in man is shown in Figure 1; this necrotising stromal keratitis represents by far the most common form of highly destructive HSK ophthalmologists must treat. It is also the most challenging and frustrating. Antiviral therapy, which may be indicated in every instance of necrotising stromal HSK, is rarely a completely satisfactory treatment alone. Steroid therapy, which may be appropriate in many instances in an attempt to minimise tissue damage from an excessive inflammatory response, theoretically might inhibit adequate 


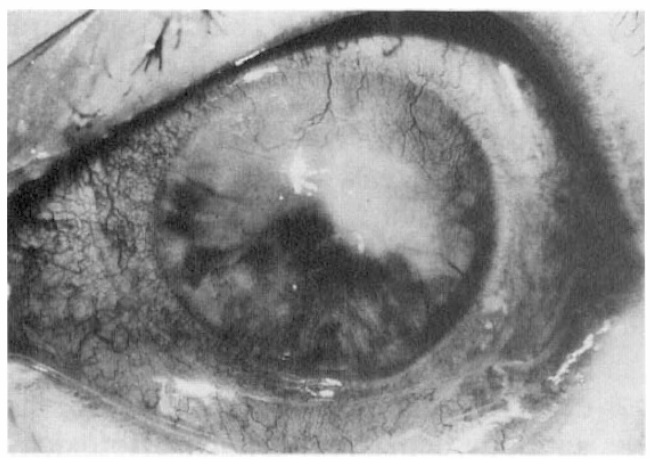

Fig. 1. Herpes Stromal Keratitis, Interstitial, Necrotising Type.

Note the profound degree of cellular infiltration into the corneal stroma with the associated external ocular inflammatory signs.

viral clearance through natural and acquired immune mechanisms, and certainly can be associated with inhibition of new collagen synthesis, with resultant uncompensated stromal ulceration. Attempts better to understand and treat stromal HSK in humans have been hampered by the genetic diversity of the patients, by the heterogeneity of the HSV isolates encountered in a sample of humans with ocular herpes, and in logistical and ethical considerations which make immunologic research in humans especially difficult.

It is for these reasons that we turned our attention to murine model of necrotising stromal HSK. We wished to define host factors which influence clinical expression of disease after encounter with herpes; and we wished, through better understanding of these host factors, to design better therapeutic strategies for modifying the inflammatory response to HSK and hence for modifying the amount of corneal damage resulting from HSK. We chose the murine model to study since inbred mice provide a definable experimental system, the immune system of which closely approximates that of humans, the genetics of which are highly defined and which can be manipulated and varied in a controlled way, and the reagents for which one may choose from a wide array of commercially available materials for study of and manipulation of the immune system.

\section{Methods and Materials}

Six to 8-week-old male and female inbred mice were bred from stock breeders obtained from Jackson Laboratories (Bar Harbor, ME), and from Dr. Nissenoff (Brandeis University, Waltham, MA). Multiple experiments over the past decade have disclosed no differences in 6,7, and 8-week-old mouse responses in our experiments, nor have any differences in male and female mice been detectable. Our recent experiments, therefore, have employed mixtures of both male and female mice. Mice were housed in microisolators mounted in a ventilated animal rack (VR-1 Lab Products, Inc.) The use of animals in this investigation conformed to National Institutes of Health guidelines. The panel of mice employed in our experiments, along with their background genetic heritage, their immune response gene phenotype (H-2), and their Igh-1 phenotype are shown in Tables I and II. As the results of our experiments increasingly pointed to the importance of the Igh-1 locus, our studies have increasingly emphasised the use of congenic strains of mice which differ only at the Igh-1 locus, i.e., Balb/c, C.A1-20, and C.B-17 mice.

\section{Viruses}

Stocks of HSV type 1 strains KOS, F, MP, and $\mathrm{mP}$ were obtained for Dr. Knipe (Harvard Medical School, Boston, MA) and were passed in Vero cells (ATTC, CCL, 81) in our laboratory.

\section{Experimental Design}

Our technique for corneal inoculation, clinical scoring, assay of trigeminal ganglionic latency, histopathologic analysis, immunopathologic analysis, assay of delayed hypersensitivity, assays of anti-herpes serum antibody levels, assays of cell-mediated cytotoxicity, assays of lymphocyte proliferation in response to herpes, and techniques for immunisation have been previously reported. ${ }^{5,6}$ Briefly, mice were anaesthetised with ether and topical $0.5 \%$ proparacaine was applied. Under binocular microscopy, the right cornea of each mouse was scratched eight times (four vertical and four horizontal scratches) with a 25 -gauge needle. Five microliters of HSV type-1 suspension were inoculated into the cul-de-sac, and the lids were compressed over the cornea for 5 seconds. Controls received $5.0 \mu \mathrm{l}$ of RPMI culture medium without virus. Daily masked bio- 
Table I H-2, Igh-1 and Igk genotypes of the C57 black congenic murine strains

\begin{tabular}{lccc}
\hline Murine strain & $\begin{array}{c}\text { Chromosome 17 } \\
\text { H-2 genotype }\end{array}$ & $\begin{array}{c}\text { Chromosome 12 } \\
\text { Igh-1-genotype }\end{array}$ & $\begin{array}{c}\text { Chromosome 6 } \\
\text { Igk genotype }\end{array}$ \\
\hline C57BL10/J & $\mathrm{b}$ & $\mathrm{b}$ & $\mathrm{b}$ \\
C57BL10.A/SgSnJ & $\mathrm{a}$ & $\mathrm{b}$ & $\mathrm{b}$ \\
C57BL.10D2n/SnJ & $\mathrm{d}$ & $\mathrm{b}$ & $\mathrm{b}$ \\
C57BL/6J & $\mathrm{b}$ & $\mathrm{b}$ & $\mathrm{b}$ \\
\hline
\end{tabular}

Table II H-2, Igh-1 and Igk genotypes of the Balb/c and the A/J congenic murine stains

\begin{tabular}{lccc}
\hline Murine strain & $\begin{array}{c}\text { Chromosome 17 } \\
\text { H-2 genotype }\end{array}$ & $\begin{array}{c}\text { Chromosome 12 } \\
\text { Igh-1-genotype }\end{array}$ & $\begin{array}{c}\text { Chromosome 6 } \\
\text { Igk genotype }\end{array}$ \\
\hline Balb/c & $\mathrm{d}$ & $\mathrm{a}$ & $\mathrm{b}$ \\
C.AL/20 & $\mathrm{d}$ & $\mathrm{d}$ & $\mathrm{b}$ \\
C58AL/20 & $\mathrm{d}$ & $\mathrm{d}$ & $\mathrm{a}$ \\
A/J & $\mathrm{a}$ & $\mathrm{e}$ & $\mathrm{b}$ \\
A.BY/SnJ & $\mathrm{b}$ & $\mathrm{e}$ & $\mathrm{b}$ \\
AKR/J & $\mathrm{k}$ & $\mathrm{d}$ & $\mathrm{a}$ \\
\hline
\end{tabular}

microscopic observations were performed, and clinical parameters were scored. HSV lid lesions, conjunctival inflammation, epithelial keratitis, stromal keratitis, and anterior chamber cellular reaction were each graded on a scale of 0 to $4+$.

Randomly selected members of each study sample were killed on days 2 and 4 after inoculation; blood was harvested for herpes-specific antibody determinations and for mononuclear cell isolation, and eyes were harvested for histopathology and for immunofluorescence studies. The specimens for histopathology were fixed in Karnovsky's fixative, embedded in JB4 plastic, sectioned at $1 \mu \mathrm{m}$, and stained with alkali Giemsa or with haematoxylin and eosin. Tissue for immunologic studies were immediately embedded in Tissue Tek II OCT embedding compound (Lab Tex Products, Inc., Naperville, IL), and cryostat sectioned at $4 \mu \mathrm{m}$. Direct immunofluorescence staining was performed with fluorescein-conjugated rabbit antisera to mouse $\operatorname{IgG}, \operatorname{IgA}, \operatorname{IgM}$, third component of mouse complement, and antiserum directed against HSV.

Anti-Herpes Antibody Determination. Serum was isolated from blood collected from tail veins. A modified, direct enzyme-linked immunosorbent assay was used to measure anti-HSV antibody titres. HSV (KOS strain) was inactivated under ultraviolet light for 20 minutes. A dilution of inactivated virus $\left(10^{7}\right.$
$\mathrm{PFU} / \mathrm{ml}$ ) was made in $0.1 \mathrm{M}$ sodium carbonate, pH 9.6, with $0.2 \%$ sodium azide. This antigen solution was plated into 96-well, flat-bottomed, polystyrene microtitration plates (0.35-ml well capacity) at $0.2 \mathrm{ml} / \mathrm{well}$. The plates were then incubated for four hours at room temperature, washed three times with $0.9 \% \mathrm{NaCl}$ with $0.05 \%$ Tween 20 , and then blocked for one hour with $0.2 \mathrm{ml} /$ well of $1 \%$ bovine serum albumin in phosphate-buffered saline with $0.05 \%$ Tween 20 and $0.2 \% \mathrm{NaN}_{3}$. The plates were again washed three times, and $0.1 \mathrm{ml}$ of the appropriate dilution of experimental serum in phosphate-buffered saline with $0.05 \%$ Tween 20 and $0.2 \% \mathrm{NaN}_{3}$ was added for a two-hour, room temperature incubation. The plates were washed three times, and alkaline-phosphatase-conjugated goat anti-mouse immunoglobulins, $F(a b) 2$ fragment specific, purchased from Dynatech Diagnostics, Inc., South Windham, ME, was added at 1:100 in phosphate-buffered saline with $0.05 \%$ Tween 20 and $0.02 \% \mathrm{NaN}_{3}$, at $0.1 \mathrm{ml} /$ well. The plates were incubated overnight at room temperature and washed three times once more. The $0.2 \mathrm{ml}$ of $2 \mathrm{mg} / \mathrm{ml}$ p-nitrophenylphosphate (Sigma Chemical Co., St. Louis, MO) in $0.05 \mathrm{M}$ sodium carbonate, $\mathrm{pH} 9.8$, with $10^{-3} \mathrm{M} \mathrm{MgCl}_{2}$ was added to each well. After a 45-minute incubation at room temperature, the reaction was stopped by addition of $0.1 \mathrm{ml}$ of $1 \mathrm{NNaOH}$ to each well. 
The absorbance at $405 \mathrm{~nm}$ was then measured with a microtitration plate reader (Flow Laboratories, McLean, VA). A well was read as positive if the absorbance was more than double that of a control well containing the dilution of nonimmune serum.

In Vitro Lymphocyte Proliferation. Briefly, $2 \times 10^{5}$ mononuclear cells, prepared in singlecell suspension from draining lymph nodes were suspended in $0.1 \mathrm{ml}$ of RPMI 1640 tissue culture medium supplemented with $2 \mathrm{mM}$ glutamine, $50 \mathrm{U}$ of penicillin, and $50 \mathrm{mg}$ of streptomycin. Triplicate samples were placed into wells of microculture plates. An additional $0.1 \mathrm{ml}$ of medium, containing appropriate concentrations of stimulatory mitogens or of herpes simplex antigen was added. The plates were incubated in a humidified atmosphere of $5 \% \mathrm{CO}_{2}$ in a water-jacketed incubator, and blastogenic transformation was measured by examining the uptake by proliferating cells of ${ }^{3} \mathrm{H}$-thymidine, $0.5 \mathrm{Ci} /$ well, at three days for mitogens and at seven days for herpes antigen. The cultures were pulsed with the radioactively labelled thymidine four hours before harvesting and analysis.

The harvested cells were washed onto glass fibre filters, dried overnight at room temperature, and placed into scintillation vials containing scintillation fluid. The vials were counted in a beta-scintillation counter, and the results were expressed as the stimulation index (i.e., counts per minute of cells incubated with control substance or antigen).

Preparation of Herpes Simplex Antigen. Herpes simplex type-1 (KOS strain), was prepared on Vero cell monolayer cultures. The pooled Vero cell suspension was frozen and thawed two times, then sonicated for two minutes in the cold. The disrupted cells were centrifuged, and the supernatant, containing live virus, was inactivated with ultraviolet irradiation. The preparation was tested for infectivity by culture on Vero cell fibroblast cultures, and stored frozen at $-70^{\circ} \mathrm{C}$. Control antigens were prepared in the same way from uninfected cultures.

Delayed-Type Hypersensitivity (DTH) Responses. Five days after the ocular inoculation, left foot pads were injected with $10^{7} \mathrm{PFU}$ UV inactivated HSV-1; 24 hours after this challenge, left and right foot pads were measured with a Fowler micrometer (Schlesinger Tool, Brooklyn, NY), and the difference in size was used as an index of DTH. All measurements were masked with respect to experimental groups.

Group means, standard errors, and standard errors of the means were calculated, and statistical significance of differences between the means was assessed with Student's t-test. All studies have been performed multiply with large groups of animals.

Ganglionic latency was determined by classical co-cultivation technique on Vero cell monolayers and by immunoperoxidase analysis of ganglia using C-DNA probes for HSV DNA in the absence of late (gamma) HSV proteins.

\section{Results}

Inbred mice exhibit major differences in susceptibility to development of necrotising stromal keratitis after HSV corneal inoculation.

Differences in susceptibility to developing HSK after HSV corneal inoculation was striking among the various inbred strains of mice studied. A/J mice $\left(\mathrm{H}-2^{\mathrm{a}}\right.$, Igh $\left.-1^{\mathrm{e}}\right)$ AKR mice $\left(\mathrm{H}-2^{\mathrm{k}}, \mathrm{Igh}-1^{\mathrm{d}}\right)$, and $\mathrm{ABY}$ mice $\left(\mathrm{H}-2^{\mathrm{b}}\right.$, Igh $\left.-1^{\mathrm{e}}\right)$ developed extreme degrees of necrotising stromal keratitis, frequently leading to corneal perforation, while C57BL/6J $\left(\mathrm{H}-2^{\mathrm{b}}\right.$, Igh $\left.-1^{\mathrm{b}}\right), \mathrm{C} 57 \mathrm{BL} 10 . \mathrm{E} 2 \mathrm{n} / \mathrm{SnJ}\left(\mathrm{H}-2^{\mathrm{d}}, \mathrm{Igh}-1^{\mathrm{b}}\right)$ C57BL10/SySnj $\quad\left(\mathrm{H}-2^{\mathrm{a}}, \quad \mathrm{Igh}-1^{\mathrm{b}}\right), \quad$ and C57BL 10/J $\left(\mathrm{H}-2^{\mathrm{b}}, \mathrm{Igh}-1^{\mathrm{b}}\right)$ developed little to no keratitis after the same HSV inoculum. Balb/c $\left(\mathrm{H}-2^{\mathrm{d}}, \mathrm{Igh}-1^{\mathrm{a}}\right)$ mice developed keratopathy intermediate to the aforementioned groups (Figs. 2 and 3). The differences can be obscured by altering the inoculum strength. By reducing the number of infectious particles in the inoculum, the degree of keratopathy in the susceptible mice is reduced, and eventually approaches that of the resistant mice. Similarly, raising the inoculum results in the emergence of significant keratopathy in the resistant mice. Similarly, the HSV isolate employed plays a profound role, but the pattern remains unchanged. That is, when the appropriate experimental dose is employed, mice susceptible to severe keratopathy with one HSV isolate are always found to be susceptible to other isolates, relative to mice which 


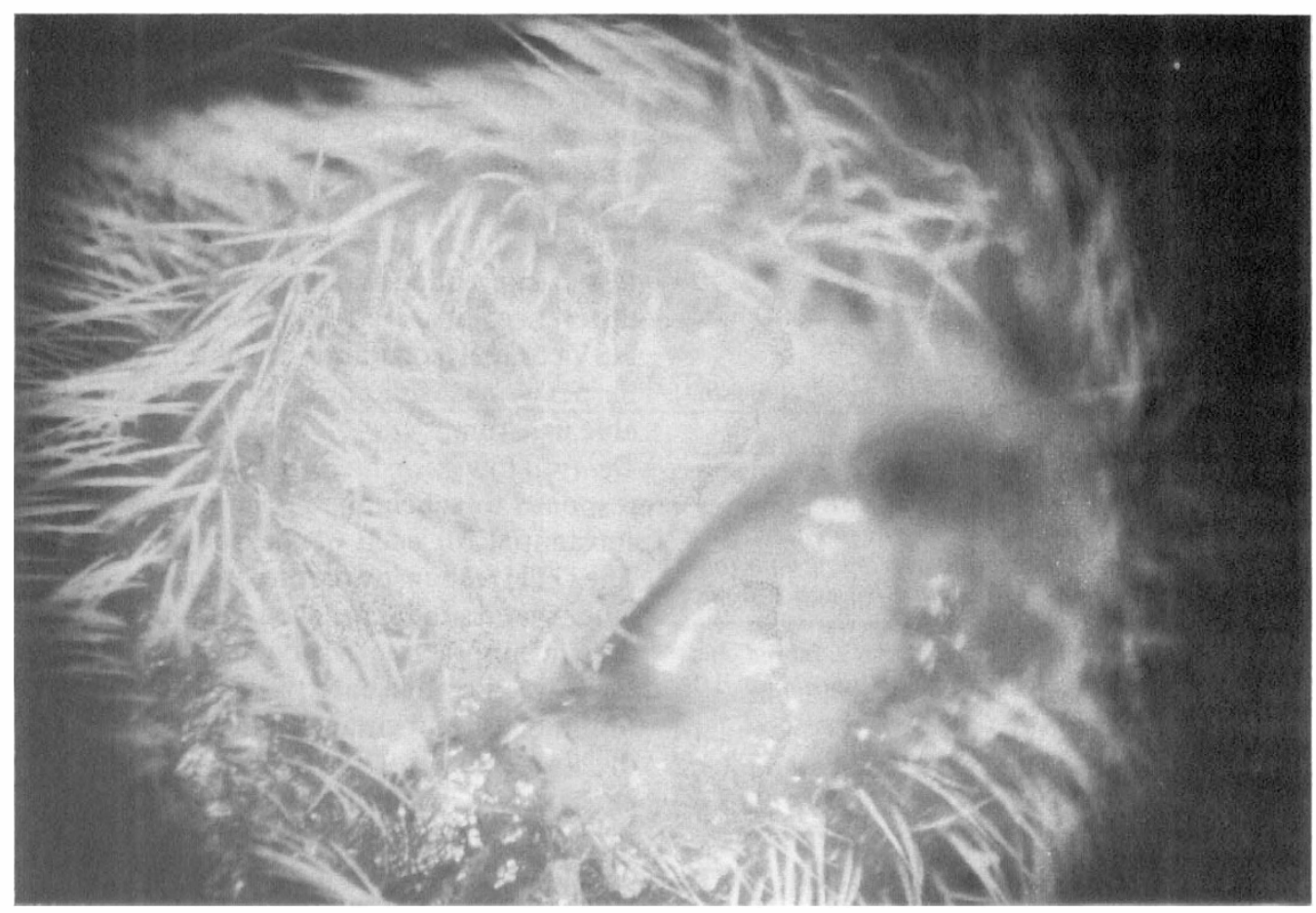

Fig. 2. Murine Model of Stromal Herpes Simplex Keratitis, Interstitial, Necrotising Type.

Histopathology of this model correlates well with that of the human equivalent seen in Figure 1, with neutrophils and macrophages the predominant infiltrating cells which are producing the corneal destruction.

are resistant to HSV keratopathy (Table II). Figure 4 demonstrates unequivocally that this difference in keratopathy susceptibility is not associated with the immune response gene; keeping background genetics and the Igh-1 phenotype constant and varying only the $\mathrm{H}-2$ phenotype results in similar keratopathy patterns. In striking contrast, varying only the Igh -1 phenotype discloses major differences in keratopathy development (Fig. 5). Balb/c (Igh-1 ${ }^{\text {a) }}$ mice developed modest keratopathy, whereas C.AL20 (Igh-1 ${ }^{d}$ ) develop extreme keratopathy $(\mathrm{P}<0.003)$. Genetic variation at the Igk-V locus has no influence on this phenomenon; C58AL-20 mice $\left(\mathrm{Igh}-1^{\mathrm{d}}, \mathrm{Igk}-\mathrm{V}^{\mathrm{a}}\right)$ develop keratopathy identical to that of C.A1-20 $\left(\mathrm{Igh}-1^{\mathrm{d}}, \mathrm{Igk}-\mathrm{V}^{\mathrm{b}}\right)$ mice. Breeding of C.B-17 congenics allowed us to refine further our studies. Table III and Figure 5 show that C.B-17 mice $\left(\mathrm{Igh}-\mathrm{1}^{\mathrm{b}}\right)$ are extremely resistant to HSV-induced keratopathy compared to identical mice which differ only at the Igh -1 locus: Balb/c $\left(\operatorname{Igh}-1^{\mathrm{a}}\right)$ and C.AL20 $\left(\operatorname{Igh}-1^{\mathrm{d}}\right)$
$\mathrm{P}<0.00001)$. It should be emphasised that these differences in HSV-induced disease susceptibility can in no way be explained by differences in the ability of the keratocytes from these congenics to support HSV replication, since Table IV shows quite clearly that the ability of pure in vitro cultures of keratocytes from these three congenic strains support HSV replication equally.

\section{Histopathologic and Immunopathologic Correlates Show Differences Between Susceptible and Resistant Mice.}

The histopatholgic correlates of these clinical differences are also striking. Susceptible mice develop a pronounced neutrophil and macrophage response in the cornea with associated stromal destruction; the mononuclear cells found at the limbus differ dramatically in surface phenotypes compared to those found in the resistant mice. Resistant mice develop a modest mononuclear cell response in the limbus and in the cornea, with almost no mac- 


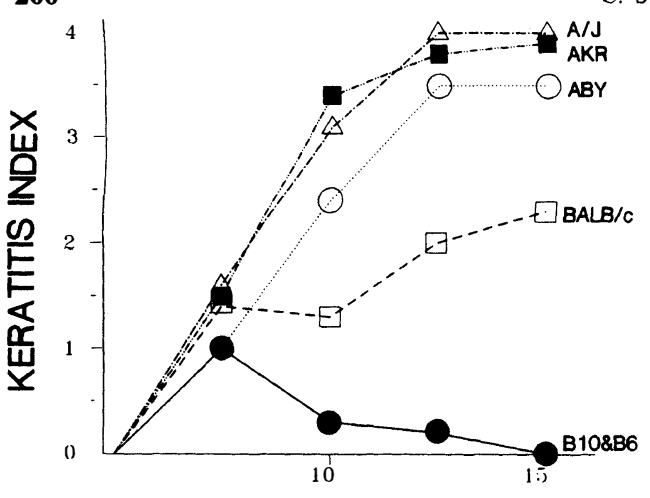

DAYS

Fig. 3. Severity of Murine Stromal HSK.

Note the dramatic differences in susceptibility of the different inbred mouse strains to developing a necrotising variety of stromal HSK, with B-10 and B-6 mice being extraordinarily resistant to developing extreme keratopathy, and $A J, A K R$, and $A B Y$ inbred mice developing extreme keratopathy after inoculation with the identical dose of $H S V$.

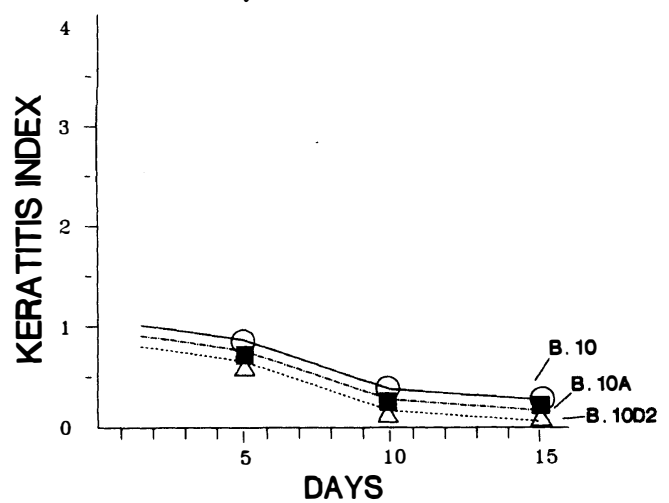

Fig. 4. Congenic B-10 mice, differing only at the major immune response gene histocompatibility locus, the H-2 locus, do not show differences in their susceptibility to necrotising stromal HSK; all show little susceptibility to development of clinically significant keratitis after HSV corneal inoculation.

rophage or neutrophil infiltration into the corneal stroma.

Immunopathologic analysis of the mononuclear cells at the corneal periphery show that, in the susceptible mice, cells of the helper/ DTH type far out number suppressor/ cytotoxic cells. This is in striking contrast to the relative proportions of helper/DTH and suppressor/cytotoxic cells at the corneoscleral limbus in resistant mice, in which suppressor/ cytotoxic cells out number helper/DTH cells (Table V).
In Vitro Immunologic Correlates

Antiherpes antibody-Antiherpes antibody titers at three different times following corneal inoculation with HSV are shown in Table VI. The data show that neutralising antibody activity is similar or identical in the three congenic strains of mice at the three time points tested, suggesting that the pronounced clinical differences observed in these mice following HSV corneal inoculation are unrelated to antiherpes neutralising antibody responses detectable in serum.

Delayed hypersensitivity response-The DTH response to subcutaneous immunisation was substantial for each of the congenic strains. The DTH response to corneal inoculations was modest and similar for each. Significant HSVspecific suppression of subcutaneously-primed DTH was found in each of the congenics after simultaneous subcutaneous and corneal priming, and the level of suppression was similar for each strain. Systemically-measurable DTH responses and DTH suppression, therefore, do not correlate with the dramatically different keratitis patterns observed in the mice (Table VII).

Lymphocyte Proliferation-In Vitro blastogenic transformation and proliferation of splenocytes in response to HSV and to mitogen exposure did differ among the congenics. But the pattern or 'rank order' of response did not

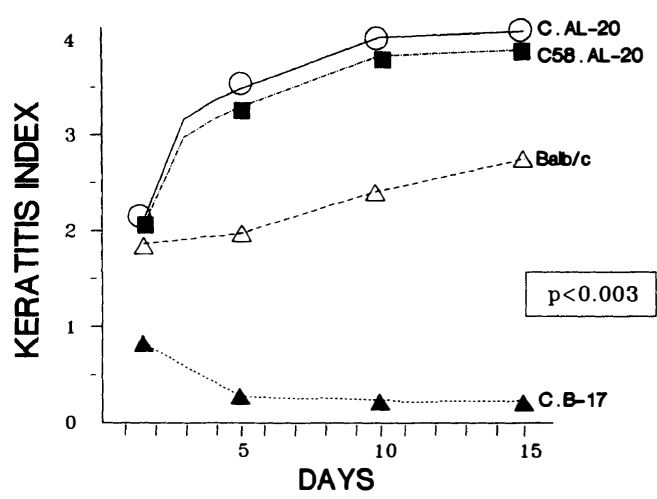

Fig. 5. Murine Stromal HSK in Balb/c Congenics. Note that in these Balb/c congenics, differing only at the Igh-1 locus, similar degrees of necrotising stromal HSK are found in those congenics which are Igh-1e or Igh Id, while Balb/c mice, which are Igh-1a are slightly less susceptible to the destructive effects of HSV inoculation and $C B-17$ mice, which are Igh $1 b$ are extremely resistant to the keratopathy. 
Table III Incidence and severity of stromal keratitis following corneal HSV-1 challenge

\begin{tabular}{|c|c|c|c|c|c|c|c|c|c|}
\hline \multirow[b]{2}{*}{ Strain } & \multicolumn{3}{|c|}{$\begin{array}{l}1.25 \times 10^{4} \mathrm{PFU} \\
\text { keratitis score }\end{array}$} & \multicolumn{3}{|c|}{$\begin{array}{l}2.5 \times 10^{4} \mathrm{PFU} \\
\text { keratitis score }\end{array}$} & \multicolumn{3}{|c|}{$\begin{array}{l}5.0 \times 10^{4} P F U \\
\text { keratitis score }\end{array}$} \\
\hline & 0 & $1-2+$ & $3-4+$ & 0 & $1-2+$ & $3-4+$ & 0 & $1-2+$ & $3-4+$ \\
\hline C.AL-20 & 5 & 1 & 2 & 3 & 3 & 11 & 2 & 0 & 8 \\
\hline $\mathrm{BALB} / \mathrm{c}$ & 8 & 0 & 2 & 6 & 1 & 3 & 4 & 1 & 6 \\
\hline C.B-17 & 7 & 0 & 0 & 15 & 1 & 1 & 8 & 1 & 2 \\
\hline
\end{tabular}

Table IV Congenic murine keratocyte permissivity to HSV-1 strain KOS

\begin{tabular}{lccc}
\hline Mouse strain & $\begin{array}{c}\text { Multiplicity } \\
\text { of infection }\end{array}$ & $\begin{array}{c}\text { Virus production } \\
\left(P F U / 10^{5} \text { cells }\right)\end{array}$ & $P$-value \\
\hline C.AL-20 & 5 & $11.6 \pm 2.9(\mathrm{~N}=5)$ & NS \\
BALB/c & 5 & $9.6 \pm 3.0(\mathrm{~N}=5)$ & NS \\
C.B-17 & 5 & $11.4 \pm 2.7(\mathrm{~N}=5)$ & NS \\
\hline
\end{tabular}

correlate with the rank order of keratitis severity for the three. Thus, while C.AL-20 mice, which are the most susceptible to severe HSK, consistently exhibited a hyper-responsiveness to both mitogens and to $\mathrm{HSV}$ relative to $\mathrm{Balb} / \mathrm{c}$ and to C.B-17 mice, the C.B-17 mice, which are the most resistant to HSK show an in vitro lymphocyte responsiveness to HSV and to mitogens which is not the highest or lowest but rather intermediate to the response of C. AL-20 and Balb/c mice (Table VIII).

Herpes-specific cytotoxic $T$ cell activityThe differences observed in detectable herpesspecific cytotoxic $T$ cells harvested from spleen or from regional draining lymph nodes from the three cogenic strains are striking (Fig. 6). Once more, however, the rank order of CTL activity does not parallel that of susceptibility to keratitis.

Taken together these findings show that these three strains of mice, which are genetically identical except for a very circumscribed area on chromosome 12 , respond differently to herpes simplex virus, both clinically (ocularly) and immunologically. The cellular and molecular details explaining how the various components of the systemic and ocular immunologic response to HSV govern the clinical outcome of HSV corneal encounter are still incompletely understood. Our current level of understanding, however, is clearly greater than that of a decade ago. It is clear that the major contributors to pathema in the cornea after HSV inoculation are inflammatory cells, and in particular neutrophils and macrophages. Our results further suggest that inadequate immunoregulation, in particular through insufficient suppressor T-cell modula-

Table V Differential cellular recruitment in Igh-1 congenic mice

\begin{tabular}{lc}
$\begin{array}{c}\text { Corneal challenge with } \\
\text { Mouse Strain }\end{array}$ & $\begin{array}{c}1^{4} \\
\text { PFU KOS (Day 11) } \\
\text { L3T4/Lyt 2.2 }\end{array}$ \\
\hline C.AL-20 $($ Igh-1d $)$ & \\
Cornea & $4: 1$ \\
Conjunctiva & $19: 1$ \\
BALB/c $($ Igh-1 & \\
Cornea & $1: 1$ \\
Conjunctiva & 0 \\
C.B-17 (Igh-1 $)$ & \\
Cornea & $1: 8$ \\
Conjunctiva & 0 \\
\hline
\end{tabular}

Table VI Anti-HSV neutralisation titers

\begin{tabular}{|c|c|c|}
\hline Day & Strain & Titer \\
\hline 5 & $\mathrm{BALB} / \mathrm{c}$ & 0 \\
\hline 5 & C. AL-20 & 0 \\
\hline 5 & C.B-17 & 0 \\
\hline 10 & $\mathrm{BALB} / \mathrm{c}$ & $1 / 25$ \\
\hline 10 & C.AL-20 & $1 / 25$ \\
\hline 10 & C.B-17 & $<1 / 25.5$ \\
\hline 20 & $\mathrm{BALB} / \mathrm{c}$ & $1 / 50$ \\
\hline 20 & C.AL-20 & $1 / 25$ \\
\hline 20 & C.B-17 & $1 / 25$ \\
\hline
\end{tabular}

The results demonstrate the relative similarity in antibody responses among the congenic strains. (Differences of one dilution or less should not be considered significant). 
Table VII Delayed hypersensitivity responses to HSV in BALB/c congenics following subcutaneous and/or corneal priming

\begin{tabular}{|c|c|c|c|c|}
\hline & \multicolumn{4}{|c|}{ Mean Footpad swelling in microns (right-left) $N=7-9$} \\
\hline \multicolumn{5}{|l|}{ C.AL-20 } \\
\hline Naive & SQ & $\mathrm{SQ}+$ Cornea & Cornea & $\%$ Tolerance \\
\hline 10 & 97 & $29^{*}$ & 33 & 22 \\
\hline \multicolumn{5}{|l|}{ C.B-17 } \\
\hline Naive & SQ & $\mathrm{SQ}+$ Cornea & Cornea & $\%$ Tolerance \\
\hline 14 & 77 & $38^{* *}$ & 23 & 38 \\
\hline \multicolumn{5}{|l|}{$\mathrm{BALB} / \mathrm{c}$} \\
\hline Naive & SQ & $\mathrm{SQ}+$ Cornea & Cornea & $\%$ Tolerance \\
\hline 7 & 52 & $25^{*}$ & 28 & 41 \\
\hline
\end{tabular}

${ }^{*} \mathrm{p}<.01$ (vs SQ alone)

${ }^{* *} \mathrm{p}<.05$ (vs SQ alone)

Table VIII Lymphocyte proliferation stimulation index

\begin{tabular}{lcc}
\hline & Con A & $H S V$ \\
\hline Balb/c: Naive & 40.0 & 0 \\
Balb/c: Subcue HSV & 33.0 & 2.62 \\
Balb/c: corneal HSV & - & 4.21 \\
C.B-17: Naive & 87.6 & 0 \\
C.B.-17: Subcue HSV & 21.6 & 7.77 \\
C.B-17: Corneal HSV & & 10.35 \\
C.AL-20: Naive & 124 & 0 \\
C.AL-20: Subcue HSV & 17.6 & 6.26 \\
C.AL-20: Corneal HSV & - & 12.08 \\
\hline
\end{tabular}

tion, may account, at least in part, for the extreme inflammatory response seen in the corneas of susceptible mice after HSV corneal inoculation, and that more efficient suppressor T-cell regulation of inflammatory responses accounts, at least in part, for the lack of such keratopathy in the resistant mice. Furthermore, these results suggest that there may be therapeutic strategies which could be exploited to reduce the tissue destruction and loss of function associated with herpetic ocular disease.

\section{Discussion}

Herpetic disease is a problem of major epidemiologic importance, with profound medical and economic consequences from ocular and from genital manifestations. The herpes epidemic continues to increase as a problem in our society in spite of available excellent antiviral drugs. The major problems are those of establishment of ganglionic latency and of excessive host inflammatory

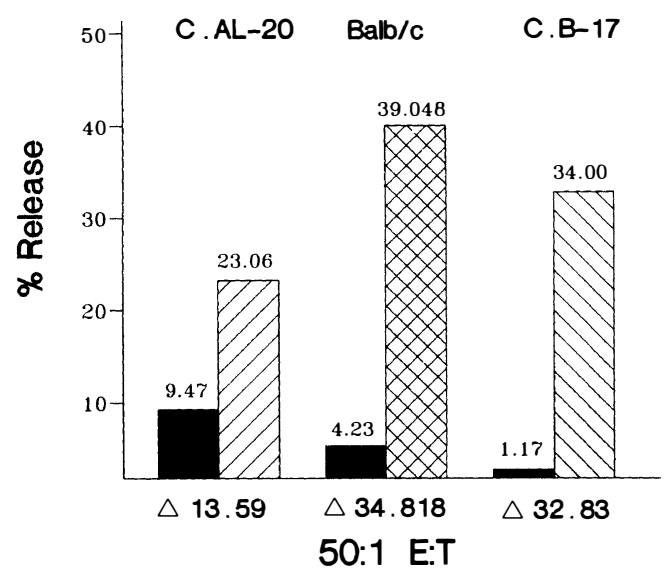

Fig. 6. Herpes Specific Cytotoxic T Cell Activity From Balb/c Congenics.

Although there are statistically significant differences among these three congenic strains, which differ only at the Igh-1 locus, the rank order of CTL activity is not the same as is the rank order of susceptibility to necrotising stromal HSK. 
responses resulting in tissue destruction sufficient to produce loss of function. Both of these problems must be solved if the herpetic problem is to be effectively eliminated.

Elimination of latent viral DNA in ganglia is a worthy goal. Conventional pharmacologic strategies are unlikely to achieve that goal; current generations of antiviral agents and those currently at the laboratory research stage are certainly incapable of achieving this goal. It is unclear what the likelihood of success within the next 30 years might be in developing specifically targeted genetic surgery designed to eliminate the viral DNA from host nuclei. The possibility of such 'magic bullet' or 'suicide pill' strategies has not escaped the attention of current researchers.

A less exotic and possibly more readily accomplished goal would be one devoted to the long-term maintenance of ganglionic latency, preventing reactivation from latency, and hence preventing the recurrent inflammatory episodes responsible for the cumulative tissue damage resulting in loss of function. Our research group has chosen this avenue. Early results from our experiments in this area strongly suggest that maintenance of ganglionic latency may be influenced by the intracellular concentrations or relative proportions of cyclic nucleotides. The results of our experiments further suggest that it may be possible to modulate the intracellular cyclic nucleotide proportions in such a way as to reduce the likelihood of viral reactivation from the latent state.

Most corneal specialists in the world today recognise that uncontrolled herpes-induced corneal and/or intraocular inflammation produces such major structural alterations in ocular tissue that the success rate of eventual visual rehabilitation through even the most elegant, expert penetrating keratoplasty is not great. Most specialists, therefore, attempt to limit the degree of host inflammation accom- panying herpetic ocular disease. Unfortunately, most conventional strategies aimed at this goal carry substantial risk of diminished HSV clearance and diminished reparative processes (e.g, new collagen formation). Titrating the exact dose of anti-inflammatory agent employed, therefore, may be extraordinarily difficult; this is particularly true in the case of corticosteroids.

We believe further research in the area of immunologic influences and immunogenetic modifications of herpes keratitis are likely to yield important clues regarding potential alternative therapeutic strategies which could be considerably more specific in limiting excessive host inflammation while at the same time not impairing host reparative processes or viral clearance. Furthermore, we believe that such therapeutic insights gained from the murine model of hepes keratitis are likely to have logical extensions to the human clinical arena.

\section{References}

${ }^{1}$ Centifano-Fitzgerald YM, Varnell ED, Kaufman $\mathrm{HE}$ : Initial herpes simplex virus Type 1 infection is genetically determined by a specific region of viral DNA. J Exp Med 1985; 155: 475-81.

2 Dawson CR, Tagni B, Moore TE: Structural changes in chronic herpetic keratitis studied by light and electron microscopy. Arch Ophthalmol 1968; 79: 740-7.

${ }^{3}$ Meyers-Elliot RH, Chitjian PA: Immunopathogenesis of corneal inflammation in herpes simplex virus stromal keratitis; role of polymorphonuclear leukocyte. Invest Ophthalmol Vis Sci 1980; 20: 86-9.

${ }^{4}$ Metcalf AF, Hamilton PS, Reichert RW: Herpetic keratitis in athymic (nude) mice. Infection Immunity 1979; 26: 1164-71.

${ }^{5}$ Foster CS, Opremcek EM, Rice R, Wells P, Chung H, Thompson P, Fong LP, Raizman M: Clinical, pathologic, and immunopathologic characteristics of experimental murine herpes simplex virus stromal keratitis and uveitis in controlled by gene products from the Igh 1 locus on Chromosome 12. Trans Am Ophthalmol Soc 1987; 85: 293-311.

${ }^{6}$ Foster CS, Tsai Y, Monroe JG: et al. Genetic studies on murine susceptibility to herpes simplex keratitis, Clin Immunol Immunopathol 1986; 40: 31320. 